University of Nebraska - Lincoln

DigitalCommons@University of Nebraska - Lincoln

2006

\title{
A Spatially Explicit Decision Support Model for Restoration of Forest Bird Habitat
}

Daniel J. Twedt

USGS-Patuxent Wildlife Research Center, dan_twedt@usgs.gov

William B. Uihlein III

U.S. Fish andWildlife Service, bill_uihlein@fws.gov

A. Blaine Elliott

U.S. Fish andWildlife Service

Follow this and additional works at: https://digitalcommons.unl.edu/usgsstaffpub

Twedt, Daniel J.; Uihlein, William B. III; and Elliott, A. Blaine, "A Spatially Explicit Decision Support Model for Restoration of Forest Bird Habitat" (2006). USGS Staff -- Published Research. 612.

https://digitalcommons.unl.edu/usgsstaffpub/612

This Article is brought to you for free and open access by the US Geological Survey at DigitalCommons@University of Nebraska - Lincoln. It has been accepted for inclusion in USGS Staff -- Published Research by an authorized administrator of DigitalCommons@University of Nebraska - Lincoln. 


\title{
A Spatially Explicit Decision Support Model for Restoration of Forest Bird Habitat
}

\author{
DANIEL J. TWEDT ${ }^{*}$ WILLIAM B. UIHLEIN III, $†$ AND A. BLAINE ELLIOTT $\dagger$ \\ *USGS-Patuxent Wildlife Research Center, 2524 South Frontage Road, Suite C, Vicksburg, MS 39180, U.S.A., \\ email dan_twedt@usgs.gov \\ †U.S. Fish and Wildlife Service, Lower Mississippi Valley Joint Venture Office, 2524 South Frontage Road, Vicksburg, MS 39180, U.S.A.
}

\begin{abstract}
The bistorical area of bottomland hardwood forest in the Mississippi Alluvial Valley has been reduced by $>75 \%$. Agricultural production was the primary motivator for deforestation; bence, clearing deliberately targeted higher and drier sites. Remaining forests are bighly fragmented and bydrologically altered, with larger forest fragments subject to greater inundation, which has negatively affected many forest bird populations. We developed a spatially explicit decision support model, based on a Partners in Flight plan for forest bird conservation, that prioritizes forest restoration to reduce forest fragmentation and increase the area of forest core (interior forest $>1 \mathrm{~km}$ from "bostile" edge). Our primary objective was to increase the number of forest patches that harbor $>2000$ ba of forest core, but we also sought to increase the number and area of forest cores $>5000 \mathrm{ha}$. Concurrently, we targeted restoration within local $\left(320 \mathrm{~km}^{2}\right) \mathrm{landscapes}$ to achieve $\geq 60 \%$ forest cover. Finally, we emphasized restoration of higher-elevation bottomland hardwood forests in areas where restoration would not increase forest fragmentation. Reforestation of $10 \%$ of restorable land in the Mississippi Alluvial Valley (approximately 880,000 ha) targeted at priorities established by this decision support model resulted in approximately 824,000 ba of new forest core. This is more than 32 times the amount of core forest added through reforestation of randomly located fields (approximately 25,000 ba). The total area of forest core (1.6 million $\mathrm{ba}$ ) that resulted from targeted restoration exceeded habitat objectives identified in the Partners in Flight Bird Conservation Plan and approached the area of forest core present in the 1950 s.
\end{abstract}

Key Words: afforestation, bird conservation, bottomland hardwood forests, conservation planning, landscape planning, reforestation

Un Modelo de Soporte de Decisiones Espacialmente Explícito para la Restauración del Hábitat de Aves de Bosque

Resumen: La superficie bistórica del bosque maderas duras en el Mississipi Alluvial Valley se ba reducido en $>75 \%$. La producción agrícola fue el principal motivo de la deforestación, mediante la tala de sitios más elevados y secos seleccionados deliberadamente. Los bosques remanentes están muy fragmentados e bidrológicamente alterados, los fragmentos más grandes están sujetos a mayor inundación, lo que ha afectado negativamente a muchas poblaciones de aves de bosque. Desarrollamos un modelo de soporte de decisiones espacialmente explícito, basado en un plan de Partners in Flight para la conservación de aves de bosque, que prioriza la restauración de bosques para reducir la fragmentación de bosques e incrementar la superficie de núcleo de bosque (bosque interior $>1 \mathrm{~km}$ de borde "bostil"). Nuestro objetivo primario fue incrementar el número y superficie de núcleos de bosque $>5000$ ba. Concomitantemente, enfocamos la restauración en paisajes locales $\left(320 \mathrm{~km}^{2}\right)$ para alcanzar $\geq 60 \%$ de cobertura forestal. Finalmente, enfatizamos la restauración de bosques de maderas duras en altitudes mayores en áreas en las que la restauración no incrementaría la fragmentación de bosques. La reforestación de 10\% de tierras restaurables en el Mississipi Alluvial Valley ( $\sim 880,000$ ha) encaminada a prioridades establecidas por este modelo de soporte de decisiones resultó en 824,000 ba de núcleo de bosque nuevo. Esto es más de 32 veces la cantidad de núcleo añadido por medio de la reforestación de campos localizados aleatoriamente ( 25,000 ha). El área total de núcleo de bosque

Paper received September 4, 2004; revised manuscript accepted March 1, 2005. 
(1.6 millones de ha) que resultó de la restauración excedió los objetivos de hábitat identificados en el Plan de Conservación de Partners in Flight y se aproximó a la superficie de núcleo de bosque presente en la década de 1950.

Palabras Clave: aforestación, bosque de maderas duras, conservación de aves, planificación de conservación, reforestación

\section{Introduction}

The onus of defining an ecologically sustainable landscape rests with the conservation community. To develop sustainable management plans under increasing pressures from burgeoning human populations (e.g., urban sprawl, degraded water quality) and heightened sociopolitical and economic liabilities (e.g., budgetary constraints, fiscal accountability), the conservation community will increasingly rely on innovative methods and emerging technologies. Adaptive resource management, geographic information systems (GIS), and Web-based databases are being used to expand our knowledge of ecological processes and to define and design spatially explicit, biologically sustainable landscapes. These methods and technologies empower land managers to depart from the conventional paradigm of an opportunity-based pursuit of habitat gains and embrace an explicit, ecologically based, strategic pursuit of landscape sustainability. We developed a spatially explicit, GIS-based, decision support model for bird conservation that prioritizes forest restoration in the Mississippi Alluvial Valley based on explicit, testable assumptions of how interior forest birds respond to fragmentation of bottomland hardwood forests. This decision support model offers natural resource planners and land managers a resource for considering alternative forest restoration projects and assessing their biological benefit to forest-breeding birds. It also provides the scientific community opportunities to advance the understanding of population and habitat relationships through research designed to test the assumptions used to develop this model.

\section{Landscape Alterations and Implications for Forest-Breeding Birds}

Forested wetlands historically occurred on $>10$ million ha within the Mississippi Alluvial Valley. Flood control has drastically altered the hydrology within this floodplain and intensified conversion of bottomland hardwood forests to agriculture (MacDonald et al. 1979; Dahl 1990). As a result, only $24 \%$ (2.6 million ha) of the floodplain remains in forest (Twedt \& Loesch 1999).

Early settlers found ease of access and arability of ridges and benches in the floodplain well suited for clearing forest and planting crops. Progression of deforestation coincided with soil arability, relative position, and hydrologic connectivity. Forest types that historically flooded for $\leq 2$ months per year (e.g., blackgum [Nyssa sylvatica biflora Walt.], American holly [Ilex opaca Ait.], and swamp chestnut oak [Quercus michauxii Nutt.]cherrybark oak [Q. pagoda Raf.] forest types) are greatly diminished within the Mississippi Alluvial Valley compared with other southeastern bottomlands (Rudis 2001). Forests on topographic flats and in swales that are subject to frequent inundation have also been cleared but to a lesser extent than drier forest types. For example, Rudis (2001) reported bald cypress (Taxodium distichum L.)water tupelo (Nyssa aquatica L.) forests suffered only a 9\% loss; overcup oak (Q lyrata Walt.)-water hickory (Carya aquatica Nutt.) forests declined by 31\%, and sweetgum (Liquidambar styraciflua L.)-Nuttall oak ( $Q$ nuttallii Palmer)-willow oak ( $Q$ phellos L.) forests had $41 \%$ loss, whereas other mixed hardwoods suffered $>61 \%$ loss.

Spatial influences driving selective deforestation affected floristic composition of bottomland hardwoods and resulted in an ecoregion that is highly fragmented. By 1992 there were $>38,000$ forest patches with a mean area of only 64 ha (Twedt \& Loesch 1999). Although smaller forest fragments tend toward drier forest types, they suffer more human-induced perturbations (e.g., livestock, nonbiodegradable refuse, buildings) than do larger fragments (Rudis 1995). Additionally, small fragments have high edge-to-area ratios; thus, interior forest is not buffered from agricultural and urban influences that may increase predation and nest parasitism of breeding birds (Batary \& Baldi 2004). Despite extensive deforestation of bottomland forests, most forest area within the Mississippi Alluvial Valley remains in large forest patches. These large forest fragments are now dominated by forest types adapted to permanently or semipermanently flooded systems (Twedt \& Loesch 1999), but they tend to have more forest core, less anthropogenic perturbations, and increased presence of Spanish moss (Tillandsia usneoides L.) (Rudis 1995). Spanish moss is used by several species of breeding birds for nest construction (Baicich \& Harrison 1997).

Alteration of the Mississippi Alluvial Valley forest landscape through hydrologic change and fragmentation has negatively affected avian populations (Smith et al. 1996). Within forests subject to frequent or prolonged flooding, birds that nest or forage on the forest floor (e.g., Kentucky Warbler [Oporornis formosus] and Swainson's 
Warbler [Limnothlypis swainsonii]) have little suitable habitat for territory establishment (Graves 2001). In smaller forest patches, forest birds are subjected to (1) more competition with other species (Kerpez \& Smith 1990), (2) increased parasitism from Brown-headed Cowbirds (Molothrus ater; Robinson \& Wilcove 1994), (3) increased likelihood of predation (Andrén \& Angelstam 1988; Marzluff \& Restani 1999), (4) greater disturbance from human activities (Knight \& Gutzwiller 1995), and (5) increased isolation and inhibition of dispersal (Doak et al. 1992; Matthysen \& Currie 1996).

For successful reproduction, many breeding birds require interior forest areas that are free from frequent human disturbance (Whitcomb et al. 1981; Marzluff \& Ewing 2001) and afford protection from predators, nest parasites, and competitors. Furthermore, for those species that retain a breeding population within small fragments, their productivity may be diminished such that they cannot replace themselves. Thus, small fragments may harbor "sink" populations that rely on emigration from other populations for continued existence (Brawn \& Robinson 1996). Both extirpation and reduced productivity threaten avian diversity within small and degraded bottomland forest fragments.

To mitigate detrimental effects associated with small forest patches and sparsely forested landscapes, conservation biologists recommend establishing corridors among patches (Sieving et al. 2000) and buffering patches to increase their size and interior area (Marzluff \& Ewing 2001). Huxel and Hastings (1999) suggest that both objectives are achieved through restoration proximate to existing forest. Further, Scott et al. (2001) state that the location of restoration sites within the landscape is critical to achieving biological success and caution against restorations that fail to contribute to regional species and ecosystem conservation goals. Thus, to restore habitat for use by forest birds, the location of potential habitat restoration sites must be identified and prioritized. Prioritization should direct restoration to locations that most benefit target species and reduce haphazard, unfocused restorations.

For restoration to be effective and relevant to wildlife populations, natural processes must also be restored (George \& Zack 2001). Unfortunately, flood mitigation projects within the Mississippi Alluvial Valley have so markedly altered hydrology that most of the vast area influenced by levees and drainage canals will not have natural hydrology restored. Hydrologic regimes on many reforested sites, however, can be locally restored through artificial, anthropogenically maintained flooding.

Because we hope to return to forest bottomland areas that were historically forested but have been converted to other use, we refer to these changes as reforestation. We reserve use of the term afforestation for conversion to forest of areas that have not historically been forest.

\section{Bird Conservation Planning and Implementation}

The North American Bird Conservation Initiative (NABCI 2000) is an international effort to increase coordination and collaboration among a broad array of conservation partners engaged in planning, implementing, and evaluating independent national and international bird conservation plans (e.g., North American Waterfowl Plan, Partners In Flight [PIF], United States Shorebird Plan, the North American Wading Bird Plan). A premise on which this conservation initiative operates is that each autonomous bird conservation plan is developed such that, when fully implemented, avian populations will be sustained at prescribed levels range wide. Individual plans introduce broad conservation objectives for their respective North American bird populations, but acknowledge that effective strategies for ecologically linking on-the-ground management actions with national conservation plans require intensive biological planning at an ecoregional scale.

In the Mississippi Alluvial Valley bird conservation region, ornithologists and land managers have responded through the development of a regional PIF Bird Conservation Plan (Twedt et al. 1998). Authors of this regional bird conservation plan identify the importance of conserving avian species that breed in bottomland hardwood forests and emphasize developing and maintaining discrete forest patches. Specifically, the plan calls for establishing and maintaining 101 bottomland hardwood forest patches capable of sustaining populations of targeted avian species. Minimum recommended size of each forest patch is 4000 ha, but approximately half of these forest patches should exceed 8000 ha. If forest patches are relatively compact (i.e., not long and narrow), an area of 4000 ha contains approximately 2000 ha of forest core, whereas 5000 ha of forest core occur in 8000 ha forest patches. Because this ecoregion is now dominated by agriculture, PIF conservation planners made a conservative recommendation that optimal forest habitat (forest core) be $>1 \mathrm{~km}$ from "hostile" habitats (e.g., agricultural fields, pasture, and urban areas) that may increase predation, nest parasitism, or human intrusion.

We presumed forest cores support populations of bird species that are self-sustaining (i.e., source populations) with sufficient territorial individuals for enhanced pair bonding (Van Horn et al. 1995). Therefore, all forest core benefits breeding forest birds, but there are advantages to establishing several widely separated forest cores instead of a few large ones. Multiple, dispersed bird populations promote morphological and presumably genetic differentiation along a latitudinal cline and guard against extirpation due to local catastrophes.

To support bird conservation within the Mississippi Alluvial Valley, we developed a spatially explicit decision support model that prioritizes the location of forest restoration to achieve PIF habitat objectives. Our primary 
goal was to defragment the existing forest through the use of restoration foci. In decreasing order of priority, these foci increased (1) the number forest cores $>2000 \mathrm{ha}$, (2) the number of forest cores $>5000 \mathrm{ha}$, (3) the percent forest in local $\left(320 \mathrm{~km}^{2}\right)$ landscapes, and (4) the area of forest cores that currently exceed 5000 ha. Within the above criteria, we gave increased priority to restoration of higher-elevation bottomland forests that are less subject to flooding.

\section{Methods}

\section{Data Sources and Model Constraints}

To determine the location and extent of existing forest, we extracted forest classes (deciduous, evergreen, mixed, and transitional forests, orchards, and woody wetlands) from U.S. Geological Survey (USGS) National Land Cover Data (30-m resolution data, Vogelmann et al. 2001). National Land Cover Data (accuracy of classification available from http://landcover.usgs.gov/accuracy/) were supplemented with a classification of forest cover based on 1992 Landsat thematic mapper (TM) imagery (Twedt 1996; Twedt \& Loesch 1999, 5-8\% commission error and $6 \%$ omission error) and an update of this classification based on 1999 TM imagery (J. Holden, unpublished data). All forested habitat identified within any of these three classifications was considered forested and merged into a single forest class.

All forest areas $>1 \mathrm{~km}$ from habitats potentially hostile to forest-breeding birds (e.g., cropland, pasture, grassland, aquaculture, urban, and suburban) were considered forest interior or core. We considered agricultural habitats hostile because of the presence of Brown-headed Cowbirds (Thompson et al. 2000) and because the ecotone created with forested habitats promotes predator incursions (Saracco \& Collazo 1999). We considered aquaculture hostile because the mowed dikes and food (intended for fish) attract Brown-headed Cowbirds. In addition to extant forest, we considered all reforested areas, shrublands, emergent wetlands, and natural water bodies nonhostile habitats. We extracted land-cover classes for open water, shrubland, and emergent herbaceous wetlands from USGS National Land Cover Data and augmented these data with lakes and rivers extracted from USGS Digital Line Graph hydrography data. Because we considered aquaculture ponds hostile habitat, we used digital outlines of these ponds (J. Cowart \& J. Holden, unpublished data) to identify and remove them from hydrographic data.

Determining the location and extent of recent reforestation within the Mississippi Alluvial Valley to augment our forest data was problematic, and our efforts were incomplete. We obtained reforestation data on public lands from a reforestation-tracking database maintained by the Lower Mississippi Valley Joint Venture Office (www.lmvjv.org). That office also works with partners to maintain a polygon database for private lands enrolled in the U.S. Department of Agriculture (USDA) Wetland Reserve Program and the USDA Conservation Reserve Program. We considered all lands enrolled in these two programs reforested, even though some have not yet been planted and parts may be managed as unforested wetlands.

Determining the historical location of former higherelevation bottomland forests was also difficult. These drier forest types historically occurred on ridges and benches within this floodplain's ridge-and-swale topography (Saucier 1994). Although the former distribution of these forests is unknown, we used five different sources of geospatial data to model the likely distribution of ridges and benches: (1) a soil moisture index on nonforested habitats estimated from winter TM satellite imagery (J. Holden, unpublished data); (2) local ridges and slopes identified from 30-m USGS digital elevation models (Caruso 1987) with standard algorithms coded within TNT-MIPS (MicroImages, Lincoln, Nebraska); (3) percent hydric soil extracted from soil associations defined in USDA STATSGO data (USDA 1995); (4) crop type classified from TM imagery (Bellow \& Graham 1992) that characterized an area's propensity for flooding (e.g., cotton being least likely to flood and soybean the most likely to flood); and (5) natural flood storage basins derived from multiple classified TM images (J. Holden, unpublished data).

Modest differences in local elevation within the floodplain of the Mississippi River result in poor discrimination among elevations when currently available digital elevation models are used. Similarly, the general soil associations within STATSGO data include multiple soil types, which limits the accuracy of these data as predictors of soil characteristics. Likewise, soil moisture and crop type may be inadequate to predict potential forest types. Finally, our depiction of natural flooding was limited in coverage and did not distinguish flood duration. Despite these limitations, the combination of increased proportion of nonhydric soil, decreased soil moisture, proximity to local ridges or well-drained slopes, the presence of crops typically grown on well-drained soils, and lack of historical natural flooding provided a good approximation of the locations that were once occupied by higherelevation bottomland hardwood forests.

\section{Model Development}

To determine the core area of each forest fragment, we combined all nonhostile habitat classes (i.e., forest, restored forest, shrubland, and natural water), calculated a 1-km internal distance from hostile edges, and subsequently removed all nonforested areas. We then determined the distance of every noncore pixel (30-m data) from the nearest forest core. Our GIS software assigned an 
arbitrary unit of 2 for every pixel (30-m) distance. When restricted to a distance of $\leq 10.5 \mathrm{~km}$, this resulted in a maximum distance value of $<700(2 \times 350)$. We inverted these distance measurements so that they scaled from 700 (adjacent to forest) to 0 ( $>10 \mathrm{~km}$ from forest).

We targeted restoration proximate to existing forest (Huxel \& Hastings 1999) and restricted restoration to within $10 \mathrm{~km}$ of existing forest cores because (1) Robinson et al. (1995) suggest that avian productivity is positively correlated with the proportion of forest cover within a $10-\mathrm{km}$ radius (approximately $314 \mathrm{~km}^{2}$ ); (2) a $10-\mathrm{km}$ limit allowed standardization of priorities among different objective foci (Fig. 1) and thus allowed us to assign different weights to objectives; (3) if forest restoration is unidirectional, a $10-\mathrm{km}$ span ( $5-\mathrm{km}$ radius) contains approximately 8000 ha with 5000 ha of forest core; and (4) forest restoration adds to the proportion of forest in local $\left(320 \mathrm{~km}^{2}\right)$ landscapes.

In accordance with the PIF Bird Conservation Plan, we sought to increase the number of forest patches with $>2000$ ha of forest core. This objective received the highest consideration in model development $($ model weight $=$ 4; Fig. 1). Although the PIF Bird Conservation Plan recommended approximately 50 forest patches with $>2000$ ha of forest core, we did not restrict the number of restoration patches.

Reforestation adjoining forest patches that already have substantial area of forest core is the most efficient way to achieve forest core areas that are $>2000$ ha. Thus, we emphasized (subweight $=5$; Fig. 1 ) reforestation adjoining existing forest cores of between 1000 and 2000 ha.
Because extensive reforestation is required to achieve a 2000-ha forest core objective when adding to forests with $<1000$ ha of core, we reduced emphasis (subweight $=3$ ) on reforestation near core areas between 100 and 1000 ha and placed least emphasis (subweight $=1$ ) on reforestation near forest cores of $<100$ ha (Fig. 1).

The PIF Bird Conservation Plan also recommends maintaining approximately 50 larger forest patches with forest cores $>5000$ ha. We afforded secondary importance (model weight $=3$; Fig. 1 ) to increasing the area of forest cores that are $>2000$ ha but $<5000$ ha. The PIF Bird Conservation Plan recommends 35 additional forest cores $>5000$ ha, but again we restricted neither the number nor location of restoration targets.

Acknowledging that all forest core benefits forest bird conservation, we also targeted forest restoration proximate to forest cores that were already $>5000$ ha. Because species dependent on these very large forested patches appear to be more dependent on overall forested landscapes rather than on area of forest core, we placed little emphasis (model weight $=1$; Fig. 1 ) on adding to forest cores that had already met the $>5000$-ha criterion.

To increase the proportion and continuity of forested habitat in local $\left(320 \mathrm{~km}^{2}\right)$ landscapes, we targeted forest restoration to achieve $\geq 60 \%$ nonhostile habitat within local landscapes. In local landscapes, many forest patches are small or linear and thus contain no forest core $>1 \mathrm{~km}$ from hostile habitat, but some have forest habitat that is $>500 \mathrm{~m}$ from hostile habitat ("subcore"). Theoretically, if a high proportion of the local landscape is forested, the contiguous extent of forest core is less important (Andren

\section{B. Restore Higher Elevation Forests}

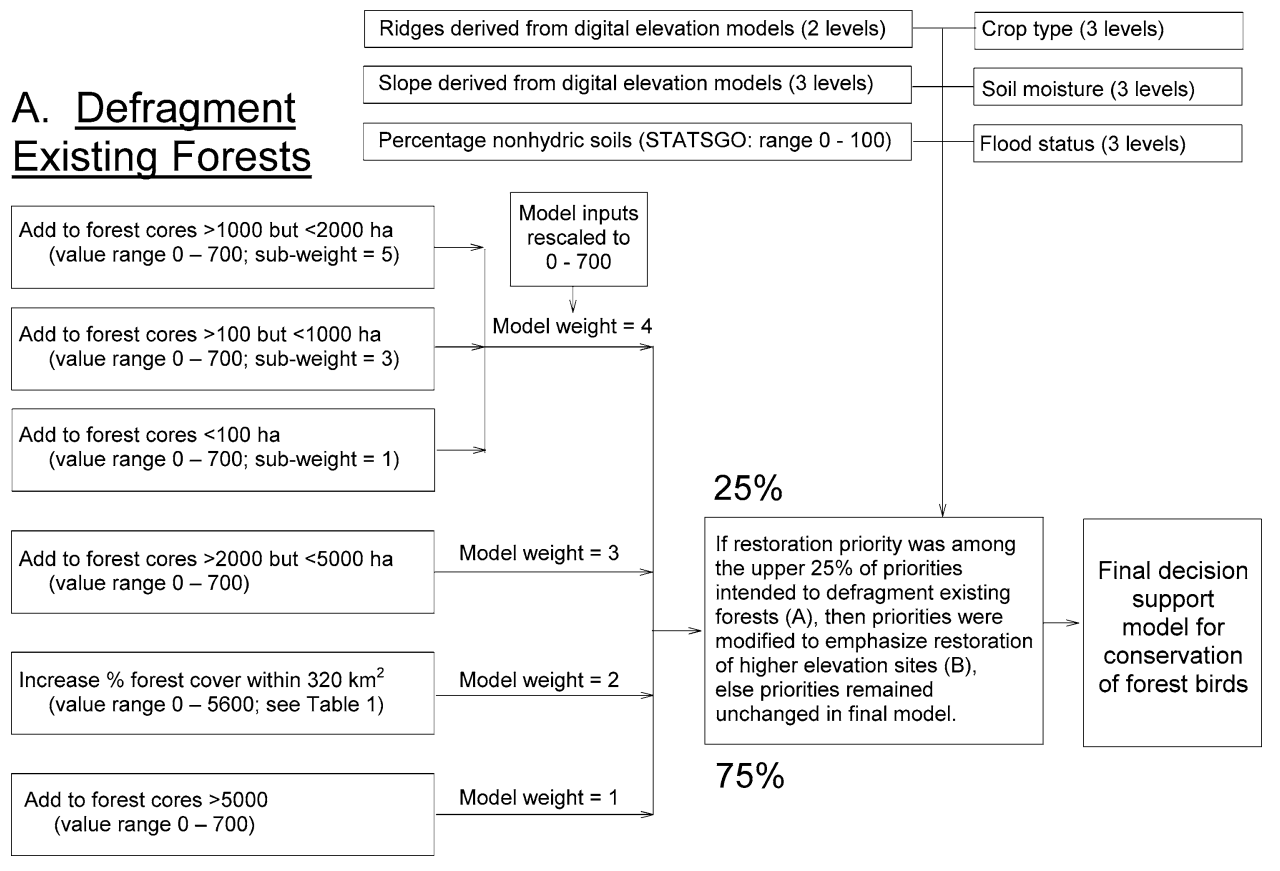

Figure 1. (a) Objectives, scaled values, and the relative weightings used to establish reforestation priorities intended to defragment bottomland hardwood forests in the Mississippi Alluvial Valley and (b) the six data sources and scaled values used to reconstruct the historical location of higher-elevation bottomland forests and the method used to combine these values into a decision support model for forest bird conservation in the Mississippi Alluvial Valley. 
Table 1. Algorithms used to assign restoration priorities to each restorable hectare in the Mississippi Alluvial Valley relative to the proportion of nonhostile habitat (forest, shrub, water) within a 320-km² local landscape.*

\section{Existing}

percentage of

nonbostile

babitat (L)

\begin{tabular}{llc}
$\begin{array}{l}\text { nonbostile } \\
\text { babitat (L) }\end{array}$ & \multicolumn{1}{c}{ Equation } & $\begin{array}{l}\text { Output } \\
\text { values }\end{array}$ \\
\hline$L<20$ & $P_{1}=2(S)+0.5 N$ & $0-1750$ \\
$20 \leq L<40$ & $P_{1}=0.1 L *[S+0.5 N]$ & $0-4200$ \\
$40 \leq L<60$ & $P_{1}=4[S+N]$ & $0-5600$ \\
$L \geq 60$ & $P_{1}=(100-0.1 L) *[0.5(S+N)]$ & $0-2800$
\end{tabular}

${ }^{*}$ Key: L, existing percentage of nonbostile habitat in $320-\mathrm{km}^{2}$ landscape; $\mathrm{P}_{l}$, priority for restoration within local landscapes; $\mathrm{S}$, inverse distance from forest habitat that is $>500 \mathrm{~m}$ from bostile babitat; $\mathrm{N}$, inverse distance from noncore forest. After applying the above equations, priority values $\left(\mathrm{P}_{l}\right)$ were restricted to $\leq 10 \mathrm{~km}$ from existing forest habitat, priority values were inversed, and values were scaled from 700 (adjacent to forest) to $O$ (>10 km from forest).

1994; Robinson et al. 1995). Therefore, to increase the proportion of forest within local landscapes, we focused reforestation proximate to subcore habitat and contiguous forest, regardless of its core area. Because additions to these subcore habitats are unlikely to result in attainment of our $>2000$-ha forest core objective and because a forested landscape objective was not identified as a priority within the PIF Bird Conservation Plan, we placed reduced emphasis (model weight $=2$ ) on increasing the percentage of forest within local landscapes.

To increase the percentage of forest in local landscapes, we placed greatest emphasis on restoration within landscapes that were between $40 \%$ and $60 \%$ forest, less emphasis on local landscapes that were between $20 \%$ and $40 \%$ forested, and least emphasis on landscapes that were either $>60 \%$ forested or $<20 \%$ forested. We derived the existing proportion of nonhostile habitat within local landscapes by calculating the percentage of nonhostile habitat surrounding each hectare within a 32,400-ha window throughout the Mississippi Alluvial Valley. We estab- lished restoration priorities within local landscapes based on algorithms that accounted for existing percent forest habitat, distance from forest, and distance from forest subcore (Table 1).

Although our final objective was to target restoration of higher-elevation forests, simply limiting restoration to areas that were formerly occupied by higher-elevation forests is inadequate for restoration of avian communities. Restoration of small, isolated forest fragments is likely to be counterproductive, regardless of forest type. Therefore, we restricted restoration of higher-elevation forest to locations that also contributed to forest defragmentation. That is, we increased the restoration priority of higherelevation forests only if their restoration contributed to the area of forest core or to more forested local landscapes. We achieved this by increasing the priority for reforestation for higher-elevation forests when they were within the top $25 \%$ of the priorities that we previously established for decreasing forest fragmentation.

\section{Model Application}

We sought to compare the potential results of the implementation of our model with historical forest conditions in the Mississippi Alluvial Valley. Toward this end, we used the same methodology we employed to determine the current area of forest core to estimate the area of forest core present in the 1950s (Table 2). This time period was selected because of the availability of maps generated from interpreted aerial photographs (USFWS 1953-1956) from which estimates of forest area could be derived and because it predates a period of extensive land clearing for agriculture during the 1960s (MacDonald et al. 1979). It was not our intention to use historical forest cover to guide future restoration, but only to provide quantitative estimates of the areas of historical and future forest cover.

To estimate the area of forest core gained under different reforestation scenarios, we evaluated the result

Table 2. Number of discrete patches $(n)$ and total area $($ ha $\times 1000)$ of forest core (i.e., forest $>1 \mathrm{~km}$ from hostile edge $)$ present ca. 1954 (historical), extant in 2002 (current), recommended in the Partners in Flight (PIF) Bird Conservation Plan for the Mississippi Alluvial Valley (Version 1.0; Twedt et al. 1998), or achieved through random or targeted reforestation of $10 \%$ of restorable land $(888,000$ ha) in the Mississippi Alluvial Valley.

\begin{tabular}{|c|c|c|c|c|c|c|c|c|c|c|}
\hline \multirow[b]{3}{*}{ Patch size (ba) } & \multirow{2}{*}{\multicolumn{2}{|c|}{ Historical }} & \multirow{2}{*}{\multicolumn{2}{|c|}{ Current }} & \multirow{2}{*}{\multicolumn{2}{|c|}{ PIF objective }} & \multicolumn{4}{|c|}{$10 \%$ restoration } \\
\hline & & & & & & & \multicolumn{2}{|c|}{ random } & \multicolumn{2}{|c|}{ targeted } \\
\hline & $\mathrm{n}$ & area (ba) & $\mathrm{n}$ & area $(\mathrm{ba})$ & $\mathrm{n}$ & area $(b a)$ & $\mathrm{n}$ & area (ba) & $\mathrm{n}$ & area (ba) \\
\hline $1-100$ & 956 & 16 & 889 & 17 & - & - & 979 & 18 & 907 & 15 \\
\hline$>100-2,000$ & 394 & 189 & 347 & 169 & - & - & 360 & 173 & 254 & 113 \\
\hline$>2,000-5,000$ & 57 & 177 & 47 & 156 & 52 & 115 & 49 & 168 & 32 & 114 \\
\hline$>5,000-34,000$ & 37 & 572 & 35 & 396 & 36 & 230 & 34 & 367 & 73 & 912 \\
\hline$>34,000$ & 13 & 1,068 & 2 & 80 & 13 & 641 & 3 & 116 & 8 & 489 \\
\hline Total $>2,000$ & 107 & 1,817 & 84 & 632 & 101 & 986 & 86 & 651 & 113 & 1,515 \\
\hline Total & 1,457 & 2,022 & 1,320 & 818 & 101 & 986 & 1,425 & 843 & 1,274 & 1,643 \\
\hline
\end{tabular}


of reforestation of the highest priority areas (top 10\%) and compared these results with multiple reforestation scenarios, each of equal reforestation effort, that randomly distributed reforestation among areas of progressively lower priority (e.g., top 20\%, top 30\%). Reforestation scenarios were simulated by "reforesting" all nonforested areas within randomly located rectangles that were of random size (between 4 and 400 ha) until the sum of reforestation equaled the target amount. We then calculated the gain in forest core under each reforestation scenario. The total area reforested approximated the restoration objective proposed by the Lower Mississippi Valley Joint Venture and field sizes of 4-400 ha were within the range of tract sizes typically enrolled in conservation easement programs. As such, our reforestation projections reflected plausible results of targeted and untargeted reforestation.

\section{Results}

We estimated that just over $8,880,000$ ha were available for reforestation out of the $11,450,000$ ha within the Mississippi Alluvial Valley Bird Conservation Region (http://www.nabci-us.org/aboutnabci/map.pdf). We elucidated $>100$ foci where additional reforestation would result in creation of forest cores that exceed 2000 ha (Fig. 2a). However, only about 50 of these areas were targeted as high priorities for restoration. Similarly, about 50 areas were deemed high priority for creation of forest cores that exceed 5000 ha (Fig. 2b). Although of lower priority for restoration, we also identified about 25 locations where additional reforestation would increase the area of forest cores that currently exceed 5000 ha (Fig. 2c).

Areas where additional reforestation will increase forest cover within local landscapes to $>60 \%$ were not mapped discretely. Generally these areas were associated with linear forest corridors along the bluffs that surround the Mississippi Valley floodplain and adjacent to riparian corridors within this floodplain (Fig. 2d).

When combined, reforestation priorities that targeted forest consolidation and more forested landscapes focused primarily on the southern portions of the Mississippi Alluvial Valley (Fig. 2e). Areas within Missouri, northern Mississippi, and northeastern Arkansas generally had lower priority for reforestation compared with Louisiana, southern Mississippi, and southeastern Arkansas. An exception was western Tennessee because this area was identified as a high priority for restoration.

Because we chose to target higher elevations for restoration only within areas that reduced fragmentation of existing forests, elevating the priority of ridges and benches did not alter the regional distribution of reforestation priorities (Fig. 2e). Local priorities, however, were modified by emphasizing restoration on higher-elevation sites (Fig. 3). The resultant decision support model for forest bird conservation is available at $30-\mathrm{m}$ resolution from http://www.lmvjv.org/GIS_data.htm.

Based on our assessment of forest core within the Mississippi Alluvial Valley, currently 84 forest cores exceed 2,000 ha, and in total encompass 632,000 ha (Table 2). About 50 years ago 1.82 million ha of forest core existed in 107 forest cores $>2,000$ ha (Table 2). Thus, in the last half century, 1.2 million ha of bottomland forest core within the Mississippi Alluvial Valley have been lost.

Premised on restoration objectives established by the Lower Mississippi Valley Joint Venture (800,000 ha) and a return to forest conditions approximating those of the 1950s, we projected the effect that reforestation of $10 \%$ of the restorable area (888,000 ha) would have on the area of forest core. Reforestation on random 4- to 400ha sites distributed throughout the Mississippi Alluvial Valley resulted in only 25,000 ha of additional forest core (Table 2). Thus, for every 36 ha reforested only 1 ha of core forest was gained. When reforestation was restricted to progressively higher priority lands, as defined by our conservation planning model, the rate of forest core gain increased only slightly until reforestation was restricted to the highest $20 \%$ of priority lands (Fig. 4). When all of the top $10 \%$ of priority lands were reforested, however, the gain in forest core $(824,000 \mathrm{ha})$ nearly equaled the area reforested (Fig. 4; Table 2).

\section{Discussion}

Historically, reforestation within the Mississippi Alluvial Valley has been driven primarily by opportunity and occurred on discrete tracts of land. Here, we simulated reforestation randomly on a finite range of "field" sizes. We acknowledge that opportunity is not necessarily random, but concomitantly, we emphasize that opportunity is likely not biologically strategic. As such, bottomland forest restoration has lacked strategic landscape-level focus without which reforestation tends to add little forest core relative to the area being reforested (Fig. 4). Actual reforestation in the Mississippi Alluvial Valley has been based on opportunity (e.g., landowner interest) but is also constrained by hydrologic, edaphic, topographic, economic, and political considerations.

Early attempts at defining restoration priorities that were based on expert opinion (Twedt et al. 1998) attempted to account for political and economic constraints through withdrawal of sites deemed unlikely to be reforested (e.g., high-quality land in cotton production). In retrospect, we believe these withdrawals from consideration were shortsighted and to the potential detriment of bird conservation. Indeed, some of the areas that were deemed "unlikely" to be restored may have already been reforested if they had been targeted as high priorities for 

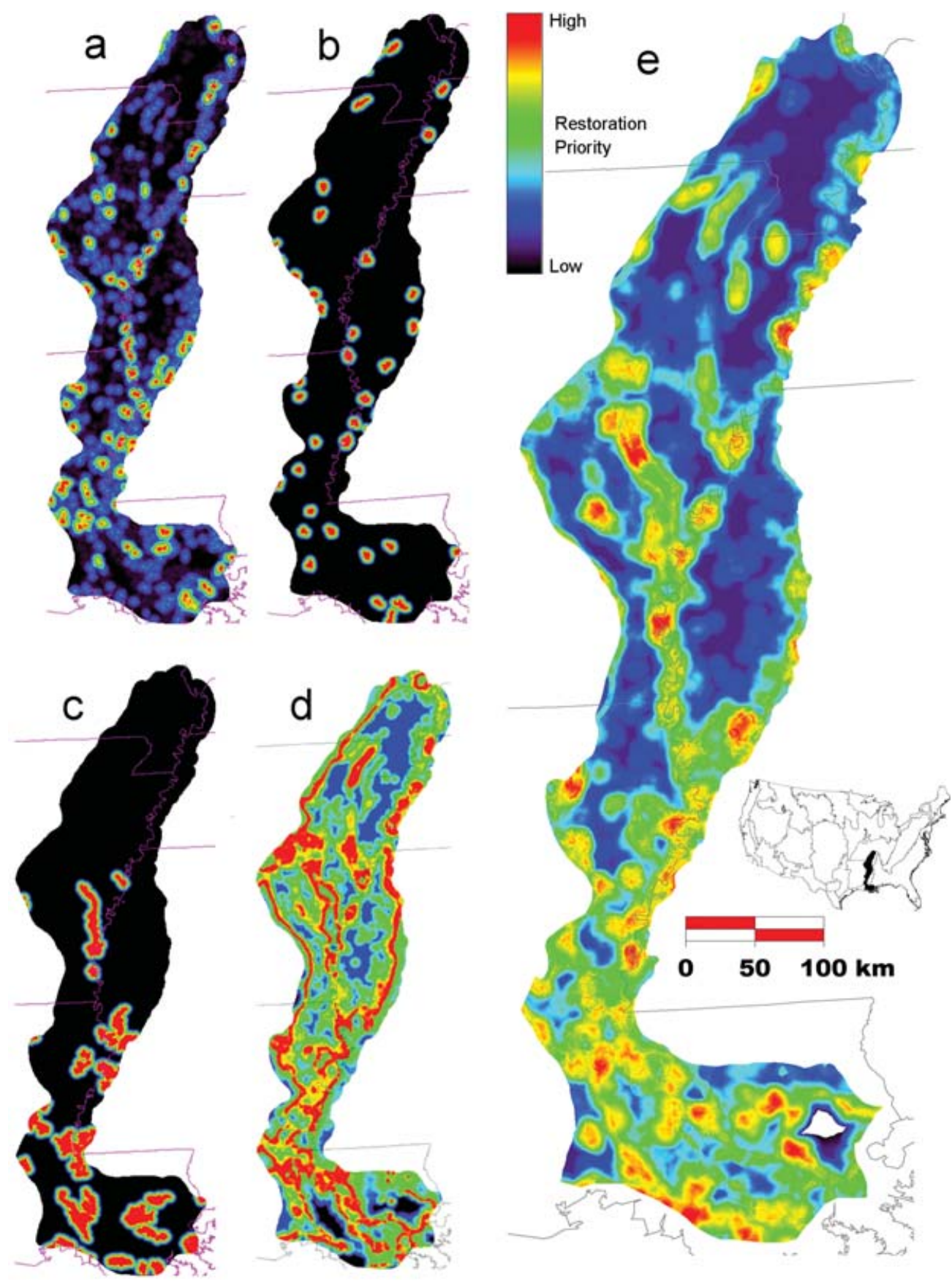

Figure 2. Locations where reforestation will benefit forest birds within the Mississippi Alluvial Valley by (a) creating forest patches with $>2000$ ba of core area, (b) creating forest patches with $>5000$ ba of core area, (c) adding to forest core areas that are currently $>5000 \mathrm{ba},(d)$ increasing the percentage of forest cover within local $\left(320-\mathrm{km}^{2}\right)$ landscapes to $>60 \%$, and (e) reducing fragmentation of existing forest patches and elevating the priority of higher-elevation sites-as a combination of the first four criteria selectively modified to emphasize restoration of higher-elevation sites.

restoration. In reality, political and economic considerations are vagile; they change with landowners, commodity prices, and government programs. Conversely, biological considerations, if based on sound science, remain relatively constant. Thus, we recommend against incorporating political and economic constraints for long-term conservation planning. Consideration of these real-world constraints will be essential for short-term implementation of conservation plans, however, and ultimately for modification of these plans.

Restoration that targets the highest priority areas in our decision support model tends to add forest core area 

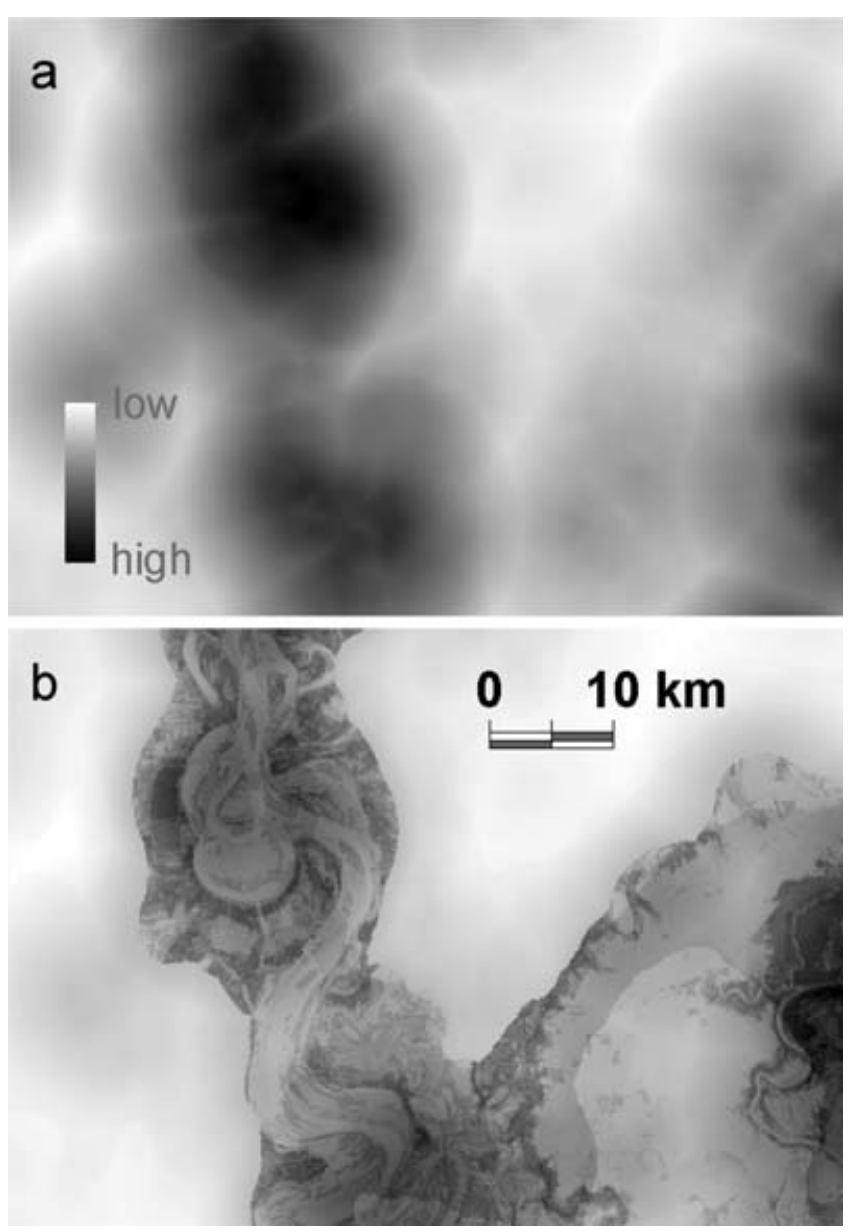

Figure 3. Reforestation priorities within the Mississippi Alluvial Valley (a) prescribed to reduce forest fragmentation and (b) modified to emphasize restoration of higher-elevation sites if they were within the upper $25 \%$ of reforestation priorities prescribed to reduce forest fragmentation.

nearly in proportion to the area reforested. If all the highest-priority areas are reforested, targets established by the PIF plan could be achieved through restoration of less than the 800,000-ha reforestation objective set by the Lower Mississippi Valley Joint Venture (Table 2). However, the distribution of forest cores may be deficient, with fewer than the historical number of discrete forest patches or the PIF target number. On the other hand, restoration of the top $10 \%$ of reforestation priority lands (888,000 ha) could increase forest core by 824,000 ha. Under this targeted restoration scenario, total forest core (1.64 million ha) would exceed the targets of the PIF plan and approach the extent of forest core present during the 1950s. In addition, the distribution of forest core patches $>2000$ ha would exceed the total number of desired patches in the PIF plan and the number present during the 1950 s.

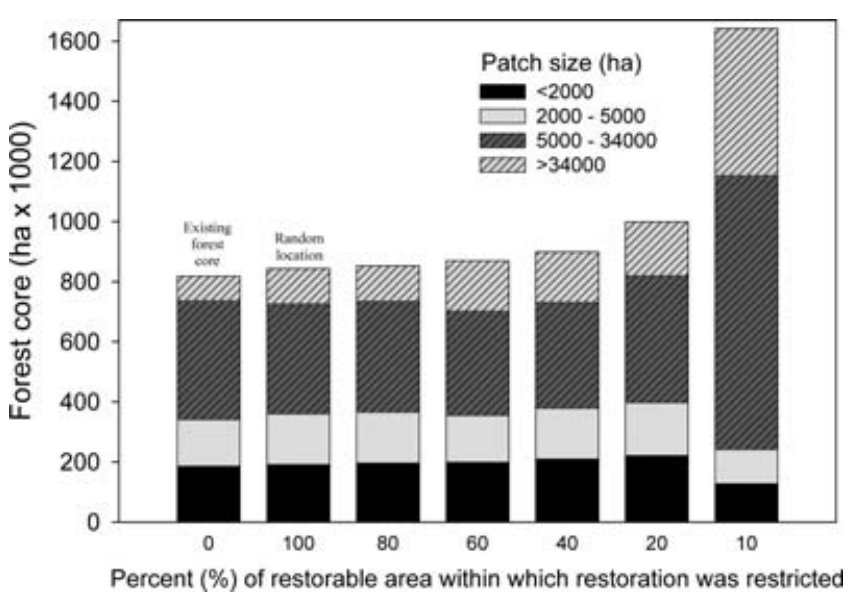

Figure 4. Total area of forest core, in contiguous patches of $<2000$ ba, 2000-5000 ba, 5000-34,000 ba, or $>34,000$ ba, that resulted from reforestation of $10 \%$ of restorable lands $(888,000 \mathrm{ba})$ under different restrictions on the placement of restoration in the Mississippi Alluvial Valley. Existing conditions are reflected at $0 \%$ restriction (i.e., no reforestation). When unrestricted (100\% of restorable area), restoration sites were randomly distributed throughout available restorable sites, whereas at $10 \%$ restriction, only restoration sites within the top $10 \%$ of restoration priorities were selected for restoration.

Achievement of the 800,000-ha reforestation objective established by the Lower Mississippi Valley Joint Venture can meet or exceed the forest-core habitat objectives of the PIF plan and provide a forested landscape equivalent to that of the 1950s. To accomplish these goals, geographic placement of forest restoration must be guided by decision support models that establish priorities for reforestation. An inappropriate use of this decision support tool, however, would be to impose conservation practices within only the highest-priority areas. Rather, this model is intended to provide science-based objectivity to a decision-making process that includes other factors (e.g., politics and economics) that also influence where conservation practices are ultimately implemented. Toward this end, state offices of the USDA Natural Resources Conservation Service are using the results of this model as one of several selection factors for enrollment in the Wetland Reserve Program.

Conservation programs often measure their success based on presumed benefits to wildlife without an explicit ecological linkage. Emerging conservation paradigms are producing new tools such as this spatial decision support model that explicitly document predicted ecological linkages. Targeting conservation programs to model outputs will improve the biological efficiencies of management actions and targeting research to underlying assumptions will improve understanding of ecological linkages. 
The reforestation priorities we established for conservation of forest birds are intended for use at regional and landscape scales. When formulating reforestation strategies at local scales, managers should refine this habitat model by considering current, historical, and future land use. Additionally, planners should involve local authorities, residents, and landowners when planning reforestation to account for the political and economic ramifications of forest restoration. Finally, planners should weigh the priorities this model establishes for forest birds against decision support models that target other species groups (e.g., bear habitat or fish-spawning areas) and perhaps emphasize areas where priorities co-occur. Regardless, targeting forest restoration to landscape-based reforestation priorities defined in our model will hasten achievement of conservation objectives for forest-breeding birds.

\section{Acknowledgments}

We thank D. Browne and J. Holden, Ducks Unlimited, Jackson, Mississippi, for sharing their geospatial data. J. Cowart assisted with import of data sets. R. Wilson provided sage counsel and review of this manuscript. Additional manuscript reviews were provided by S. Somershoe and three anonymous reviewers.

\section{Literature Cited}

Andrén, H. 1994. Effects of habitat fragmentation on birds and mammals in landscapes with different proportions of suitable habitat: a review. Oikos 71:355-366.

Andrén, H., and P. Angelstam. 1988. Elevated predation rates as an edge effect in habitat islands: a landscape perspective. Ecology 73:794804.

Baicich, P. J., and C. J. O. Harrison. 1997. A guide to the nests, eggs, and nestlings of North American birds. 2nd edition. Academic Press, San Diego, California.

Batary, P., and A. Baldi. 2004. Evidence of an edge effect on avian nest success. Conservation Biology 18:389-400.

Bellow, M. E., and M. L. Graham. 1992. Improved crop area estimation in the Mississippi Delta region using Landsat TM data. Pages 423-432 in American Society for Photogrammetry and Remote Sensing (ASPRS) and American Congress on Surveying and Mapping (ACSM) annual convention proceedings. Volume 9. ASPRS, Bethesda, Maryland, and ALSM, Gaitherburg, Maryland.

Brawn, J. D., and S. K. Robinson. 1996. Source-sink populations dynamics may complicate the interpretation of long-term census data. Ecology 77:3-12.

Caruso, V. 1987. Standards for digital elevation models. Pages 159-166 in American Society for Photogrammetry and Remote Sensing (ASPRS) and American Congress on Surveying and Mapping (ACSM) annual convention proceedings. Volume 4. ASPRS, Bethesda, Maryland, and ALSM, Gaitherburg, Maryland.

Dahl, T. E. 1990. Wetlands losses in the United States 1780's to 1980 's. U.S. Department of the Interior, Fish and Wildlife Service, Washington, D.C. Northern Prairie Wildlife Research Center, Jamestown, North Dakota. Available from http://www.npwrc.usgs. gov/resource/othrdata/wetloss/wetloss.htm (version 16JUL97) (accessed May 2005).
Doak, D. F., P. C. Marino, and P. M. Kareliva. 1992. Spatial scale mediates the influence of habitat fragmentation on dispersal success: implications for conservation. Theoretical Population Biology 41:315-336.

George, T. L., and S. Zack. 2001. Spatial and temporal considerations in restoring habitat for wildlife. Restoration Ecology 9:272-279.

Graves, G. R. 2001. Factors governing the distribution of Swainson's Warblers along a hydrological gradient in Great Dismal Swamp. Auk 118:650-664.

Huxel, G. R., and A. Hastings. 1999. Habitat loss, fragmentation, and restoration. Restoration Ecology 7:309-315.

Kerpez, T. A., and N. S. Smith. 1990. Competition between European Starlings and native woodpeckers for nest cavities in saguaros. Auk 107:367-375.

Knight, R. L., and K. J. Gutzwiller. 1995. Wildlife and recreationists: coexistence through management and research. Island Press, Washington, D.C.

MacDonald, P. O., W. E. Frayer, and J. K. Clauser. 1979. Documentation, chronology, and future projections of bottomland hardwood habitat losses in the lower Mississippi Alluvial Plain. Volume 1. U. S. Fish and Wildlife Service, Washington, D.C.

Marzluff, J. M., and K. Ewing. 2001. Restoration of fragmented landscapes for the conservation of birds: a general framework and specific recommendations for urbanizing landscapes. Restoration Ecology 9:280-292.

Marzluff, J. M., and M. Restani. 1999. The effects of forest fragmentation on avian nest predation. Pages 155-169 in J. A. Rochelle, L. A. Lehmann, and J. Wisniewski, editors. Forest wildlife and fragmentation: management and implications. Brill, Leiden, The Netherlands.

Matthysen, E., and D. Currie. 1996. Habitat fragmentation reduces disperser success in juvenile Nuthatches, Sitta europaea: evidence from patterns of territory establishment. Ecography 19:67-72.

NABCI (North American Bird Conservation Initiative). 2000. The North American Bird Conservation Initiative in the United States: a vision of American bird conservation. U.S. Fish and Wildlife Service, Division of Bird Habitat Conservation, Arlington, Virginia.

Robinson, S. K., and D. S. Wilcove. 1994. Forest fragmentation in the temperate zone and its effects on migratory songbirds. Bird Conservation International 4:233-249.

Robinson, S. K., F. R. Thompson III, T. M. Donovan, D. R. Whitehead, and J. Faaborg. 1995. Regional forest fragmentation and the nesting success of migratory birds. Science 267:1987-1989.

Rudis, V. A. 1995. Regional forest fragmentation effects on bottomland hardwood community types and resource values. Landscape Ecology 10:291-307.

Rudis, V. A. 2001. Composition, potential old growth, fragmentation, and ownership of Mississippi Alluvial Valley bottomland hardwoods: a regional assessment of historic change. Pages $28-48$ in P. B. Hamel and T. L. Foti, editors. Bottomland hardwoods of the Mississippi Alluvial Valley: characteristics and management of natural function, structure, and composition. General technical report SRS-42. U.S. Forest Service, Asheville, North Carolina.

Saracco, J. F., and J. A. Collazo. 1999. Predation on artificial nests along three edge types in a North Carolina bottomland hardwood forest. Wilson Bulletin 111:541-549.

Saucier, R. T. 1994. Geomorphology and quaternary geologic history of the lower Mississippi valley. Volume 1. U. S. Army Engineer Waterways Experiment Station, Vicksburg, Mississippi.

Scott, T. A., W. Wehtje, and M. Wehtje. 2001. The need for strategic planning in passive restoration of wildlife populations. Restoration Ecology 9:262-271.

Sieving, K. E., M. F. Willson, and T. L. DeSanto. 2000. Defining corridor functions for endemic birds in fragmented south-temperate rain forests. Conservation Biology 14:1120-1132.

Smith, W. P., P. B. Hamel, and R. P. Ford. 1996. Mississippi Alluvial Valley forest conversion: implications for eastern North American avifauna. Pages 460-469 in Proceedings 1993 annual conference. Southeastern Association of Fish and Wildlife Agencies, Tallahassee, Florida. 
Thompson, F. R., S. K. Robinson, T. M. Donovan, D. R. Whitehead, and J. Faaborg. 2000. Biogeographic, landscape, and local factors affecting cowbird abundance and host parasitism levels. Pages 186-219 in J. N. M. Smith, T. L. Cook, S. I. Rothstein, S. K. Robinson, S. G. Sealy, and J. N. M. Smith, editors. Ecology and management of cowbirds and their hosts: studies in the conservation of North American passerine birds. University of Texas Press, Austin.

Twedt, D. J. 1996. Land cover in the Mississippi Alluvial Valley. The DELTA, Lower Mississippi Valley, natural resources partnership: geospatial data collection. CD-ROM addendum to to R. M. Kress, editor. Miscellaneous paper EL-96-4, Lower Mississippi Valley Geographic Information System Steering Committee, U.S. Army Corps of Engineers, Waterways Experiment Station, Vicksburg, Mississippi.

Twedt, D. J., and C. R. Loesch. 1999. Forest area and distribution in the Mississippi Alluvial Valley: implications for breeding bird conservation. Journal of Biogeography 26:1215-1224.

Twedt, D. J., D. N. Pashley, W. C. Hunter, A. J. Mueller, C. R. Brown, and R. P. Ford. 1998. Mississippi Alluvial Valley bird conservation plan: physiographic area \#5. Partners in Flight. Version 1. Bureau of Land Management, Washington, D.C.
USDA (U.S. Department of Agriculture). 1995. State soil geographic (STATSGO) data base. Miscellaneous publication 1492. Natural Resources Conservation Service, Dallas, Texas.

USFWS (U.S. Fish and Wildlife Service). 1953-1956. Wetland maps of Arkansas (4RB-117), Louisiana (4RB-126), Mississippi (4RB-129), and the southeastern United States (4RB-227). Division of Engineering, U.S. Fish and Wildlife Service, Atlanta.

Van Horn, M. A., R. M. Gentry, and J. Faaborg. 1995. Patterns of Ovenbird (Seiurus aurocapillus) pairing success in Missouri forest tracts. Auk 112:98-106.

Vogelmann, J. E., S. M. Howard, L. Yang, C. R. Larson, B. K. Wylie, and N. Van Driel. 2001. Completion of the 1990s national land cover data set for the conterminous United States from Landsat thematic mapper data and ancillary data sources. Photogrammetric Engineering and Remote Sensing 67:650-652.

Whitcomb, R. F., C. S. Robbins, J. F. Lynch, B. L. Whitcomb, M. K. Klimkiewicz, and D. Bystrak. 1981. Effects of forest fragmentation on avifauna of eastern deciduous forests. Pages 125-205 in R. L. Burgess and D. M. Sharpe, editors. Forest island dynamics in man-dominated landscapes. Springer-Verlag, New York.

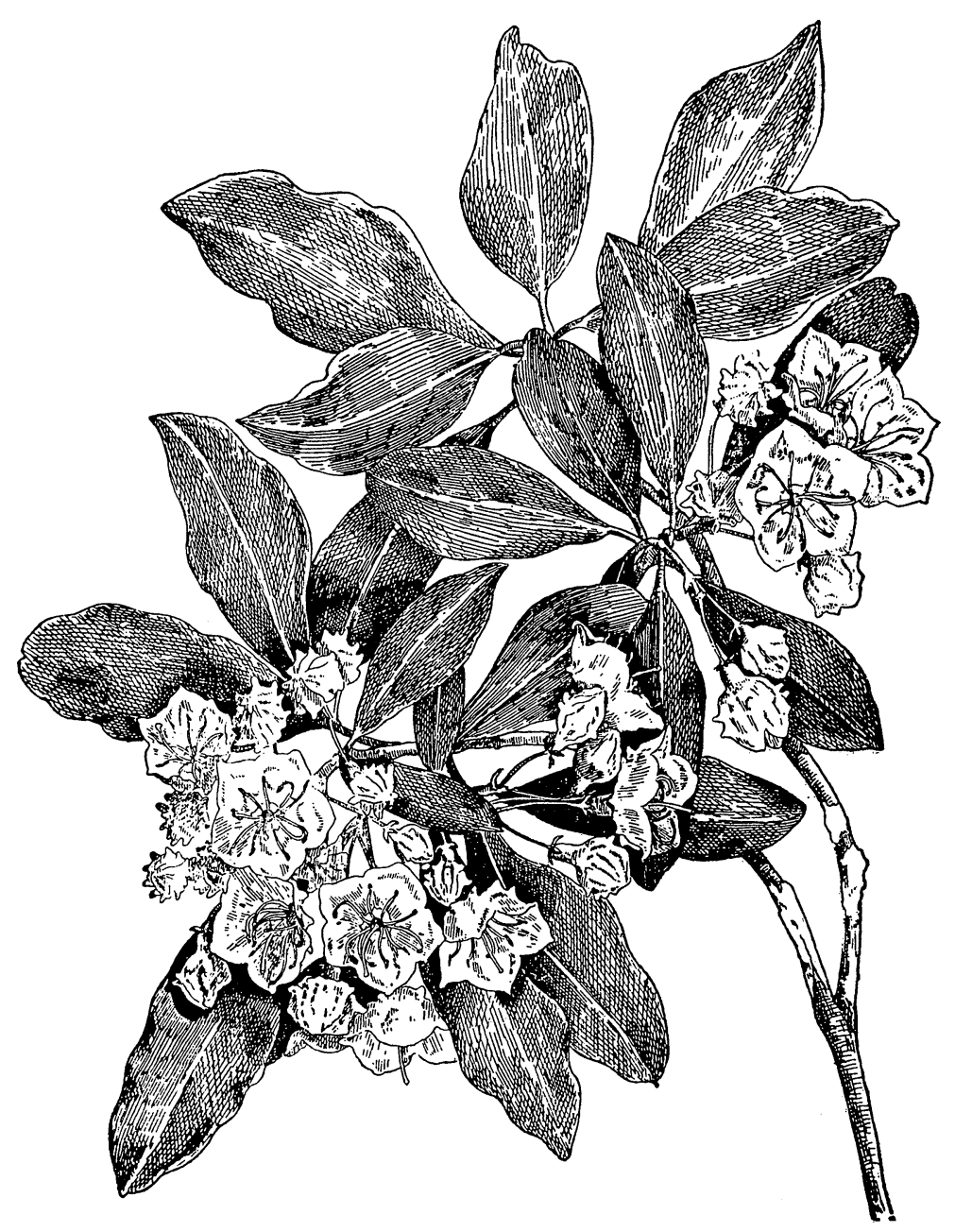

